\title{
Morphological and Phenological Attributes of Maize Affected by Different Tillage Practices and Varied Sowing Methods
}

\author{
Shakeel A. Anjum1, Ehsanullah"1*, Umair Ashraf1, Mohsin Tanveer1, \\ Rafi Qamar', Imran Khan ${ }^{1}$ \\ ${ }^{1}$ Department of Agronomy, University of Agriculture, Faisalabad, Pakistan \\ ${ }^{2}$ Department of Agronomy, University College of Agriculture, University of Sargodha, Sargodha, Pakistan \\ Email: ${ }^{\text {ehsanchahal@gmail.com }}$
}

Received 30 March 2014; revised 29 April 2014; accepted 9 May 2014

Copyright (C) 2014 by authors and Scientific Research Publishing Inc.

This work is licensed under the Creative Commons Attribution International License (CC BY). http://creativecommons.org/licenses/by/4.0/

\section{(c) (i) Open Access}

\begin{abstract}
To check the performance of maize under different tillage practices and varied sowing methods, an experiment was conducted at Agronomic Research Area, University of Agriculture, Faisalabad. The experiment was carried out in a randomized complete block design (RCBD) with split plot arrangement with three replications. Different tillage practices viz, conventional tillage, minimum tillage and deep tillage were kept in main plots while sowing methods viz, flat sowing, ridge sowing and bed sowing were allocated to subplots. The maize hybrid "Pioneer-32T16" was sown on $2^{\text {th }}$ February, 2012. Data pertaining to morphological and phenological attributes of maize showed that tillage practices and sowing methods had a significant effect on Germination count $\cdot \mathrm{m}^{-2}(7.8)$, leaf area per plant $\left(5010 \mathrm{~cm}^{2}\right)$, leaf area index (4.87), crop growth rate $\left(20.69 \mathrm{~g} \cdot \mathrm{m}^{-2} \cdot \mathrm{d}^{-1}\right)$, plant height $(213.04 \mathrm{~cm})$, number of leaves per plant (11.89), days to $50 \%$ tasseling $(\mathbf{7 2 . 4 4 )}$ and days to $50 \%$ silking (73.77). Economically, maize sown on ridges under deep tillage gave maximum net income of Rs. $85162 \mathrm{ha}^{-1}$ while minimum net income of Rs. $56984 \mathrm{ha}^{-1}$ was found where flat sowing was adopted under minimum tillage system and also more BCR of 1.70 was recorded in ridge sown maize under deep tillage.
\end{abstract}

\section{Keywords}

Maize, Growth, Tillage, Sowing Methods

\section{Introduction}

Maize is the third most important cereal crop of Pakistan after wheat and rice. Due to its multipurpose usage in "Corresponding author. 
agro-industry, it is termed as "Queen of cereals" [1]. It has high nutritive value as it contains about $0.7 \%-1.3 \%$ ash, $3.2 \%$ - 7.7\% fats, $7.7 \%$ - 14.6\% protein, $0.80 \%$ - 2.32\% crude fiber and $69.65 \%$ - $74.54 \%$ carbohydrates [2], mostly grown for three main purposes as human food, feed for poultry and fodder for livestock. About $50 \%$ to $55 \%$ of total maize production is used as food in developing countries [3]. In Pakistan, it is grown twice a year in autumn as well as spring season. The area in the country under maize is very low as compared to wheat and rice despite its importance as high worth edible oil, food for human beings, feed for farm animals and poultry and unprocessed material for miscellaneous agro-based industries [4] and desirable crop for crop rotation. It is used as staple food in many countries. It is cultivated on 1.08 million hectares area with 4.27 million tons production and $3.94 \mathrm{t} \cdot \mathrm{ha}^{-1}$ average yield [5]. This yield is low as compared to other developed countries around the globe owing to agronomic, edaphic and environmental factor including both tillage and sowing methods that affect the morphology and allometry of maize. According to Kepner [6], goal of tillage is to offer a proper environment for the seed germination, weed control and to maintain the soil moisture by increasing infiltration. Tillage is the physical manipulation of soil affecting degree of soil bulk density, soil compaction and soil moisture that ultimately affect seedling emergence and crop yield. Moreover, it is also practiced for management of previous crop residues, control of competing vegetation, and incorporation of amendments and preparation of seedbed and considered as an essential part of crop production disturbing many factors imperative to crop growth. Khurshid et al. [7] reported that tillage methods considerably affected the physical properties of soil. The soil moisture contents were higher in conventional tillage and bulk density was lesser in case of deep tillage as compared to minimum tillage. Depending upon climate, topography and soil properties, tillage practices and sowing methods vary from one area to another. Sowing is basic operation that is desired to get better yield from agriculture. Proper sowing method is one of the essential factors for successful crop yield. It guarantees the optimum plant population and supports plants to use land and other basic resources more competently for the better crop growth and development [8]. Furthermore, ridge tillage and sowing are applied in various crops and climates in order to offer labor saving, better water management, enhance soil fertility, enhance rooting depth, improve wind and water erosion control and improve pest controlling [9]. It is necessary that maize be sown using a multipurpose method that makes sure the efficient nutrients uptake, interplant competition and minimum over shading. Better sowing or planting methods increase crop yield [10]. Keeping in view the importance of cultural practices in crop yield, the present study was planned to evaluate the affect of different tillage systems and sowing methods on morphological and phenological attributes of maize.

\section{Materials and Methods}

\section{Experimental Details}

A field experiment was conducted to evaluate the effect of different tillage practices and sowing methods on the morphological and physiological attributes of maize (Zea mays L.) during spring, 2012 at Agronomic Research Area, University of Agriculture Faisalabad Pakistan. Pre-sowing soil samples were collected from experimental area with the help of a soil auger to a depth of $0-30 \mathrm{~cm}$ and then air dried for physico-chemical analysis. The soil was found to be normal but low in organic matter. Further characteristics of experimental soil are given in the Table 1. Maize hybrid "Pioneer-32T16" was sown, with $30 \mathrm{~kg} \cdot \mathrm{ha}^{-1}$ seed rate, in well prepared seed bed according to the treatments on $24^{\text {th }}$ February, 2012. The experiment was laid out in randomized complete block design (RCBD) with split plot arrangement and repeated thrice. Experiment comprised of Tillage Practices (Main-Plots) i.e., $\mathrm{T}_{1}$ : Conventional tillage (Disc harrow twice + cultivator once + planking); $\mathrm{T}_{2}$ : Minimum tillage (Cultivator twice + planking) and $\mathrm{T}_{3}$ : Deep tillage (Chisel plough twice + cultivator once + planking) as well as sowing methods (Sub-Plots) i.e., $\mathrm{S}_{1}$ : Flat sowing $(\mathrm{R} \times \mathrm{R}=60 \mathrm{~cm}) ; \mathrm{S}_{2}$ : Ridge sowing $(\mathrm{R} \times \mathrm{R}=60 \mathrm{~cm})$ and $S_{3}$ : Bed sowing $(B e d=120 \mathrm{~cm}$ ). Tractor, Planker, Hand Drill, Spade and Chisel Plough were used for tillage and sowing purpose. Fertilizer was applied @ 250:125:125 kg NPK·ha ${ }^{-1}$. Whole quantity of Phosphorus and Potash was applied prior to seeding as a basal dose while nitrogen was applied in three splits $\left(1 / 3^{\text {rd }}\right.$ at the time of sowing, $1 / 3^{\text {rd }}$ at five leaf stage and $1 / 3^{\text {rd }}$ at tasseling stage. Leaf area index (LAI) and crop growth rate (CGR) were computed by the formulae given by [11] [12], respectively.

$$
\begin{aligned}
& \mathrm{LAI}=\text { Leaf area/Land area } \\
& \mathrm{CGR}=\left(\mathrm{W}_{2}-\mathrm{W}_{1}\right) /\left(\mathrm{t}_{2}-\mathrm{t}_{1}\right)
\end{aligned}
$$

where 
Table 1. Physico-chemical properties of experimental soil.

\begin{tabular}{ccc}
\hline Texture Class & \multicolumn{2}{c}{ Sandy clay soil (Medium hard) } \\
\hline Parameter & Values & Status \\
\hline EC $(1: 2.5) \mathrm{dS} \cdot \mathrm{m}^{-1}$ & 0.15 & Non saline \\
$\mathrm{pH}$ & 8.00 & Medium alkaline \\
Organic matter (\%) & 0.27 & Very low \\
Nitrogen (\%) & 0.017 & Very low \\
Available P (ppm) & 7.5 & Low \\
Exchangable K (ppm) & 102 & Medium \\
\hline
\end{tabular}

$\mathrm{W}_{1}=$ Total dry matter at the first harvest

$\mathrm{W}_{2}=$ Total dry matter at the second harvest

$\mathrm{t}_{1}=$ Date of observation of first dry matter

$\mathrm{t}_{2}=$ Date of observation of second dry matter

All other agronomic practices was done by using standard procedures and at the end crop was harvested and cobs were removed from husk and were kept for sun drying to minimize moisture content of grain and easy shelling. After certain period of sun drying, the cobs were shelled with the help of maize sheller to separate grains from pith. The data was collected analyzed by using Fisher analysis of variance technique and significant treatment means were compared by the least significant difference (LSD) test at 0.05 probability level [13] where as economic analysis was carried out to look into comparative benefits of different treatment combinations [14].

\section{Results}

\subsection{Germination Count"m-2}

Data regarding germination count $\cdot \mathrm{m}^{-2}$ as affected by various tillage practices and sowing methods are depicted in Table 2. It is obvious from the table that there were non-significant differences in germination count $\cdot \mathrm{m}^{-2}$ when maize hybrid was sown under different tillage practices. Maximum germination count of 7.1 plants $\cdot \mathrm{m}^{-2}$ was observed in deep and minimum tillage while minimum $\left(6.7 \mathrm{~m}^{-2}\right)$ was recorded in conventional tillage but they were not varying up to the level of significance. As regard the maize sowing methods, there were significant differences in germination count $\cdot \mathrm{m}^{-2}$. Maximum germination count $\left(7.8 \mathrm{~m}^{-2}\right)$ was observed in ridge sowing that was at par with bed sowing while flat sowing attained minimum germination count of 6.1 plants $\cdot \mathrm{m}^{-2}$. Greater germination $\cdot \mathrm{m}^{-2}$ in ridge sowing might be due optimum moisture level and nutrients availability.

\subsection{Plant Height at Maturity (cm)}

Plant height at maturity was affected appreciably by different tillage practices and sowing methods. The plant height was found maximum $(213.04 \mathrm{~cm})$ in deep tillage and lowest $(201.84 \mathrm{~cm})$ in minimum tillage that was found statistically similar with conventional tillage $(204.00 \mathrm{~cm})$. As far sowing methods are concerned, ridge sown maize produced maximum plant height of $211.86 \mathrm{~cm}$ that was statistically comparable with bed sowing (210.40 cm) while minimum plant height of $196.62 \mathrm{~cm}$ was recorded in flat sowing. Moreover, interaction between tillage practices and sowing methods was found non-significant.

\subsection{Stem Diameter ( $\mathrm{mm}$ )}

Various tillage systems and sowing methods are depicted in Table 2 clarified that neither the individual factors nor the interaction affect stem diameters of maize hybrid noticeably, when it was sown with different sowing methods under different tillage practices. The stem diameter ranged from $11.30 \mathrm{~mm}$ to $13.30 \mathrm{~mm}$ but the differences were found statistically non-significant.

\subsection{Leaf Area per Plant $\left(\mathrm{cm}^{2}\right)$}

Data regarding the effect of different tillage practices and sowing methods on leaf area per plant 70 (days after 
Table 2. Effect of various tillage practices and sowing methods on rice growth and phenology.

\begin{tabular}{|c|c|c|c|c|c|c|}
\hline Treatments & $\begin{array}{c}\text { Germination } \\
\text { count } \cdot \mathrm{m}^{-2}\end{array}$ & $\begin{array}{l}\text { Plant height } \\
\text { (cm) }\end{array}$ & $\begin{array}{l}\text { Stem diameter } \\
(\mathbf{m m})\end{array}$ & $\begin{array}{c}\text { Number of leaves } \\
\text { per plant }\end{array}$ & $\begin{array}{c}\text { Days to } 50 \% \\
\text { tasseling }\end{array}$ & $\begin{array}{l}\text { Days to } 50 \% \\
\text { silking }\end{array}$ \\
\hline Conventional Tillage & 6.7 & $204.00 \mathrm{~B}$ & 11.98 & $11.60 \mathrm{AB}$ & 71.00 & 72.44 \\
\hline Minimum Tillage & 7.1 & $201.84 \mathrm{~B}$ & 11.86 & $11.36 \mathrm{~B}$ & 71.55 & 72.44 \\
\hline Deep Tillage & 7.1 & $213.04 \mathrm{~A}$ & 12.82 & $11.89 \mathrm{~A}$ & 70.22 & 71.44 \\
\hline LSD $(p \leq 0.05)$ & NS & 7.53 & NS & 0.31 & NS & NS \\
\hline Flat Sowing & $6.1 \mathrm{~B}$ & $196.62 \mathrm{~B}$ & 11.90 & 11.53 & $72.44 \mathrm{~A}$ & $73.77 \mathrm{~A}$ \\
\hline Ridge Sowing & $7.8 \mathrm{~A}$ & $211.86 \mathrm{~A}$ & 12.00 & 11.49 & $70.44 \mathrm{~B}$ & $71.44 \mathrm{~B}$ \\
\hline Bed sowing & $7.0 \mathrm{AB}$ & $210.40 \mathrm{~A}$ & 12.76 & 11.82 & $69.89 \mathrm{~B}$ & $71.11 \mathrm{~B}$ \\
\hline $\operatorname{LSD}(p \leq 0.05)$ & 0.98 & 5.90 & NS & NS & 0.85 & 1.73 \\
\hline $\begin{array}{l}\text { Conventional Tillage } \\
\times \text { Flat Sowing }\end{array}$ & 5.7 & 199.33 & 12.13 & $12.00 \mathrm{a}$ & 72.00 & 73.66 \\
\hline $\begin{array}{l}\text { Minimum Tillage } \\
\times \text { Flat Sowing }\end{array}$ & 6.0 & 193.20 & 11.67 & 11.33 a & 72.66 & 74.33 \\
\hline $\begin{array}{l}\text { Deep Tillage } \\
\times \text { Flat Sowing }\end{array}$ & 6.7 & 197.33 & 11.90 & $11.27 \mathrm{~b}$ & 72.66 & 73.33 \\
\hline $\begin{array}{l}\text { Conventional Tillage } \\
\times \text { Ridge Sowing }\end{array}$ & 7.7 & 205.26 & 11.30 & 11.33 a & 70.66 & 72.00 \\
\hline $\begin{array}{l}\text { Minimum Tillage } \\
\times \text { Ridge Sowing }\end{array}$ & 7.7 & 207.93 & 11.40 & $11.07 \mathrm{a}$ & 71.00 & 71.33 \\
\hline $\begin{array}{l}\text { Deep Tillage } \\
\times \text { Ridge Sowing }\end{array}$ & 8.0 & 222.40 & 13.30 & $12.07 \mathrm{a}$ & 69.66 & 71.00 \\
\hline $\begin{array}{l}\text { Conventional Tillage } \\
\times \text { Bed sowing }\end{array}$ & 6.7 & 207.40 & 12.50 & 11.47 a & 70.33 & 71.66 \\
\hline $\begin{array}{l}\text { Minimum Tillage } \\
\times \text { Bed sowing }\end{array}$ & 7.7 & 204.40 & 12.50 & $11.67 \mathrm{a}$ & 71.00 & 71.66 \\
\hline $\begin{array}{l}\text { Deep Tillage } \\
\times \text { Bed sowing }\end{array}$ & 6.7 & 219.40 & 13.27 & $12.33 \mathrm{a}$ & 68.33 & 70.00 \\
\hline $\operatorname{LSD}(p \leq 0.05)$ & NS & NS & NS & 0.68 & NS & NS \\
\hline
\end{tabular}

Any two means not sharing a letter in common in the same column differ significantly at $\mathrm{p} \leq 0.05$.

sowing) DAS of maize hybrid are shown in Figure 1. The leaf area was recorded at 40, 55, 70 and $85 \mathrm{~cm}^{-2}$ days after sowing. It further elucidated that leaf area per plant varied significantly when maize hybrid was sown with different sowing methods under various tillage systems. Leaf area per plant was highest in the plots where ridge sowing was practiced under deep tillage while lowest was recorded in the flat sowing under minimum tillage.

\subsection{Leaf Area Index (LAI)}

Figure 2 expounded that leaf area index (LAI) varied extensively when maize hybrid was sown with different sowing methods under various tillage systems. Maximum LAI was recorded at 40, 55 and 70 DAS in the plots where ridge sowing was done under deep tillage while minimum in the flat sown maize where minimum tillage was practiced. In the middle phase of growth, leaf area index was continued to increase while decreased towards maturity. The results were much better in conventional tillage with ridge and bed sowing. Moreover, all sowing methods except flat sowing were found effective regarding improvement of LAI.

\subsection{Crop Growth Rate (g"m-2. $\mathrm{day}^{-1}$ )}

Various tillage practices and sowing methods affected the crop growth rate (CGR) of maize hybrid under study (Figure 3). The CGR was calculated within the certain periods (40 - 55, 55 - 70 and 70 - 85 DAS) and was measured highest at all stages in the plots where ridge sowing and bed sowing was done under deep tillage while 


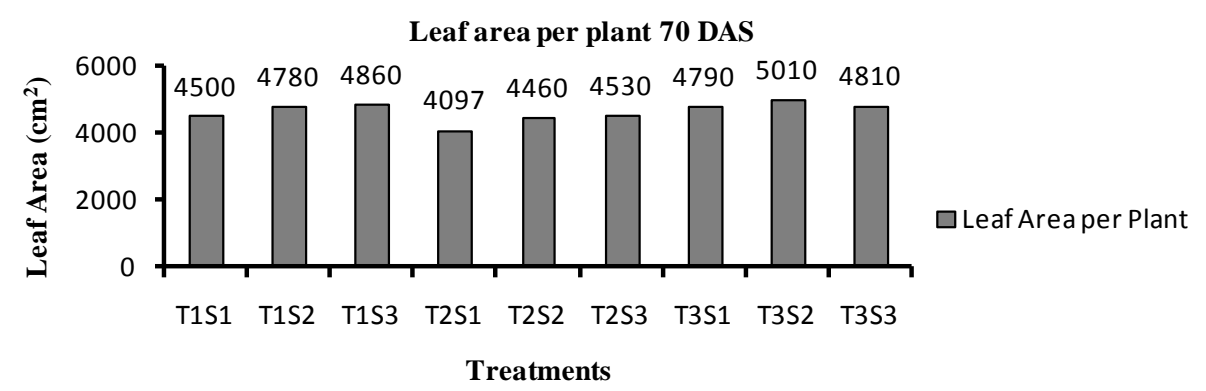

Figure 1. Effect of tillage practices and sowing methods on leaf area per plant.

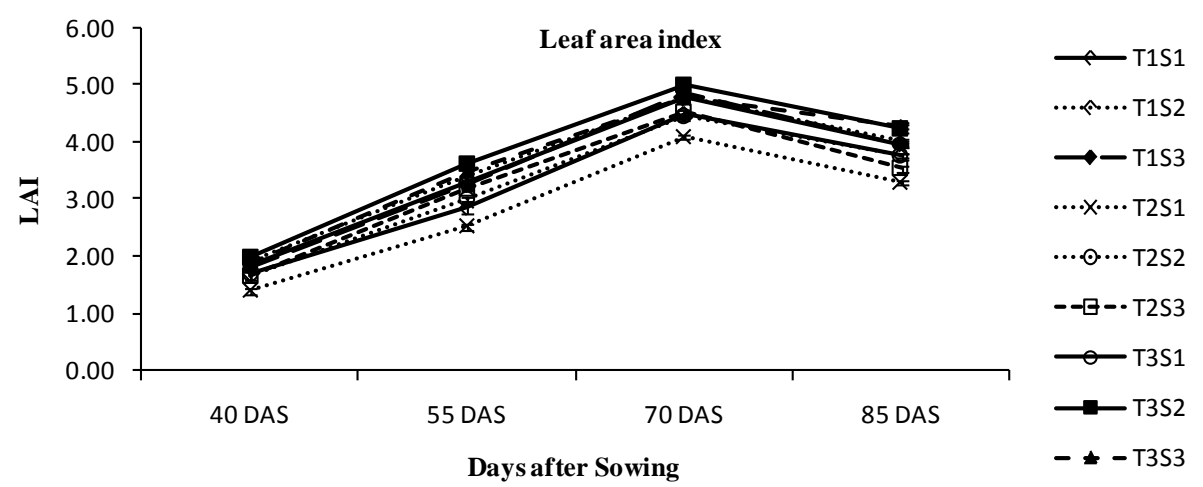

Figure 2. Effect of tillage practices and sowing methods on leaf area index (LAI).

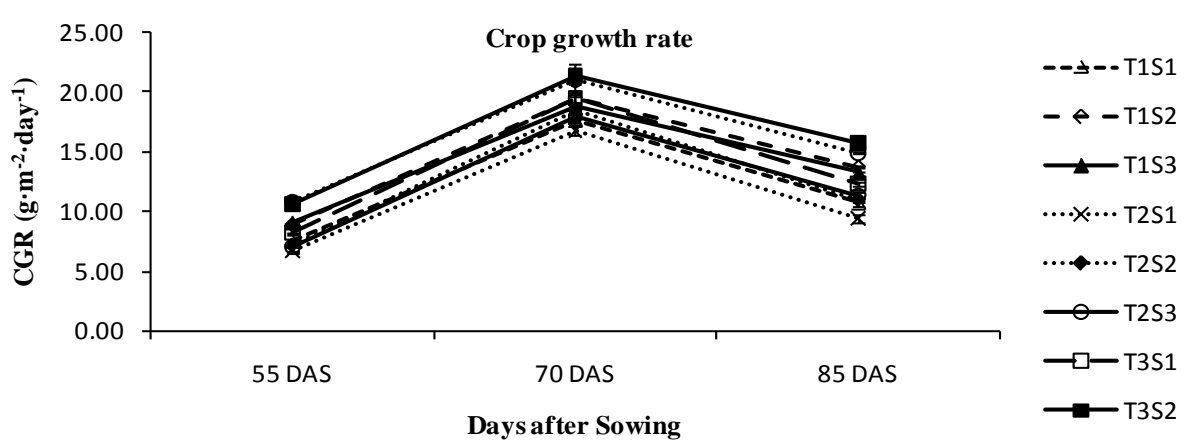

Figure 3. Effect of tillage practices and sowing methods on crop growth rate (CGR).

lowest was recorded in the flat sowing where minimum tillage was practiced. CGR continued to increase up to middle phase of growth then declined towards maturity. All sowing methods except flat sowing increased the crop growth rate. The results were much better in conventional tillage with ridge and bed sowing.

\subsection{Number of Leaves per Plant}

Table 2 illustrated that number of leaves per plant was affected radically by different tillage practices. The number of leaves per plant was higher (11.89) in the deep tillage that was at par with the conventional tillage (11.60) while lower number of leaves per plant (11.36) was found in minimum tillage that was closely followed by conventional tillage. As for sowing methods were concerned, maximum number of leaves per plant was produced in bed sown maize (11.82) while the minimum number of leaves was produced in ridge sowing (11.49) but these were not varying up to the level of significance. Furthermore, a significant interactive effect was also noted between various tillage practices and sowing methods for number of leaves per plant. All the sowing methods including flat, ridge and bed sowing showed statistically non-significant differences in the means regarding number of leaves per plant under conventional and minimum tillage. But under deep tillage, maize on ridges produced maximum number of leaves per plant (12.07) that was statistically similar with bed sown maize (12.33) 
while flat sown maize produced significantly minimum number of leaves per plant (12.27).

\subsection{Days to $50 \%$ Tasseling}

Data regarding days to $50 \%$ tasseling indicated that there were non-significant differences in days to $50 \%$ tasseling when maize hybrid was sown under different tillage practices. Maximum days to 50\% tasseling (71.55 days) were observed from minimum tillage while minimum days to 50\% tasseling (70.22 days) were recorded in deep tillage but did not differ significantly. As regard the sowing methods, there a significant difference in days to $50 \%$ tasseling was observed. Maximum days to 50\% tasseling (72.44 days) were recorded in flat sowing while minimum days were recorded in bed sown maize (69.89 days) that was similar with ridge sown maize (70.44 days).

\subsection{Days to $50 \%$ Silking}

A non-significant difference in days to $50 \%$ silking was observed when maize hybrid was sown under different tillage practices (Table 2). Maximum days to 50\% silking (72.44 days) were observed minimum tillage and conventional tillage while minimum days to $50 \%$ silking (71.44 days) were recorded in deep tillage but they were not varying up to the level of significance whereas sowing methods significantly affected to days to $50 \%$ silking. Maximum days to 50\% silking (73.77 days) were observed in flat sowing while minimum days (71.11) were recorded in bed sown maize that was similar with ridge sown maize (71.44 days).

\subsection{Economic Analysis}

It is clear from the Table 3 that highest net return of Rs. 85162 was recorded in the treatment where ridge sowing of maize hybrid was done under deep tillage while lowest net return of Rs. 56984 was recorded in flat sown maize under minimum tillage. As farmers are more interested in variability in benefits than yields, therefore net field benefits (NFB) were calculated against the variable cost. Table 3 further revealed that maximum NFB of Rs. 173788 was achieved in the treatment where ridge sowing of maize hybrid was done under deep tillage. The minimum NFB of Rs. 145610 was obtained where flat sowing was done under conventional tillage. Moreover, the efficiency of tillage practices and sowing methods on maize was determined from the benefit cost ratio. The maximum benefit cost ratio (BCR) of 1.70 was found where ridge sowing of maize was practiced under deep tillage.

\section{Discussion}

Stand establishment is pre-requisite for better crop growth and harvest of the optimum crop yield. High and rapid germination determines good stand establishment which results in higher yield. More the germination per

Table 3. Economic analysis of different tillage practices and sowing methods.

\begin{tabular}{|c|c|c|c|c|c|c|c|c|c|}
\hline \multicolumn{2}{|c|}{ Treatments } & $\begin{array}{c}\text { Grain yield } \\
\left(t \cdot h^{-1}\right)\end{array}$ & $\begin{array}{c}\text { Value } \\
\left(\text { Rs. ha }^{-1}\right)\end{array}$ & $\begin{array}{c}\text { Straw yield } \\
\left(t \cdot h^{-1}\right)\end{array}$ & $\begin{array}{c}\text { Value } \\
\left(\text { Rs. ha }^{-1}\right)\end{array}$ & $\begin{array}{l}\text { Gross income } \\
\left.(\text { Rs. ha })^{-1}\right)\end{array}$ & $\begin{array}{l}\text { Total cost } \\
\left(\text { Rs. ha }^{-1}\right)\end{array}$ & $\begin{array}{l}\text { Net return } \\
\left.(\text { Rs. ha' })^{-1}\right)\end{array}$ & $\begin{array}{c}\text { Benefit } \\
\text { cost ratio }\end{array}$ \\
\hline \multirow{3}{*}{$\begin{array}{c}\text { Conventional } \\
\text { Tillage }\end{array}$} & Flat Sowing & 5.52 & 165,600 & 10.31 & 13,403 & 179,003 & 113,806 & 65,197 & 1.57 \\
\hline & Ridge Sowing & 6.01 & 180,300 & 10.66 & 13,858 & 194,158 & 115,753 & 78,404 & 1.68 \\
\hline & Bed Sowing & 5.92 & 177,600 & 10.48 & 13,624 & 191,224 & 115,506 & 75,718 & 1.66 \\
\hline \multirow{3}{*}{$\begin{array}{l}\text { Minimum } \\
\text { Tillage }\end{array}$} & Flat Sowing & 5.04 & 151,200 & 10.40 & 13,520 & 164,720 & 107,736 & 56,984 & 1.53 \\
\hline & Ridge Sowing & 5.74 & 172,200 & 10.88 & 14,144 & 186,344 & 110,261 & 76,083 & 1.69 \\
\hline & Bed Sowing & 5.55 & 166,500 & 10.62 & 13,806 & 180,306 & 109,738 & 70,567 & 1.64 \\
\hline \multirow{3}{*}{$\begin{array}{l}\text { Deep } \\
\text { Tillage }\end{array}$} & Flat Sowing & 5.72 & 171,600 & 11.01 & 14,313 & 185,913 & 118,356 & 67,557 & 1.57 \\
\hline & Ridge Sowing & 6.40 & 192,000 & 10.76 & 13,988 & 205,988 & 120,826 & 85,162 & 1.70 \\
\hline & Bed Sowing & 6.13 & 183,900 & 11.20 & 14,560 & 198,460 & 120,083 & 78,376 & 1.65 \\
\hline ice of grain & $\begin{array}{l}\mathrm{d} \text { per ton }=\mathrm{Rs} \\
\mathrm{d} \text { per ton }=\mathrm{Rs}\end{array}$ & $\begin{array}{l}30,000 /- \\
1300 /-\end{array}$ & & & & & & & \\
\hline
\end{tabular}


square meter more will be the overall plant population which ultimately enhances the crop yield significantly. Germination is the emergence and development from the seed embryo of those essential structures which indicate the ability to produce a normal plant under favorable condition and it depends on sowing depth, soil moisture level, soil aeration, temperature and quality of the seed. Maize planted on ridges provided better stand establishment as compared to other sowing methods. Greater germination $\cdot \mathrm{m}^{-2}$ in ridge sowing might be due optimum moisture level and nutrients availability. These results were supported by Memon et al. [15] and Bakht et al. [16] who found maximum emergence \% in ridge sowing but in contradiction to Arif et al. [17] who stated that sowing methods significantly affected all parameters calculated excluding emergence $\cdot \mathrm{m}^{-2}$.

Plant height at maturity is an important morphological attribute because it is a function of combine effect of genetic makeup of plant, soil nutrition status, seed vigor and environmental conditions under which it was grown. Deep tillage was seen an improved practice regarding plant height and but flat sowing remained inefficient to improve plant height as compared to ridge and bed sowing. Borghei et al. [18] and Wasaya et al. [19] who concluded that sub-soiling up to 50 - $55 \mathrm{~cm}$ caused the highest average plant height while our results were contradictive to Najafinezhad et al. [20] who concluded that conventional tillage (CT) and reduced tillage (RT) plots exhibited highest plant height whereas stem diameter remained in effective by different tillage operations and sowing methods which was found in line with Aikins et al. [21], who concluded that maize stem girth was non-significant under different tillage practices. Moreover, deep tillage and ridge sowing improved leaf area, leaf area index and crop growth rate of maize which found in accordance with the results reported by Rasheed et al. [22] and Balasubramaniyan et al. [23] who found that maize crop sown on ridges gave considerably higher leaf area index (5.22) and further elucidated that planting methods influenced leaf area index positively and crop growth rate of maize significantly. Additionally, deep tillage and conventional tillage was found statistically similar regarding number of leaves per plant whereas a significant interaction between tillage practices and sowing methods also observed. Furthermore, flat sown maize took more days to $50 \%$ tasseling and silking than ridge and bed sowing while tillage practices did not affect to duration of crop maturation significantly. These results were in confirmation with Majid et al. [24] who during studying the effects of various maize sowing methods concluded that days to tasseling were decreased in ridge sowing. Growth parameters were improved in ridge sowing and days to 50\% tasseling and silking were significantly affected by planting methods where as an interactive effect of tillage practices and sowing methods on days to $50 \%$ silking was found to be non-significant [15].

Finally, the effectiveness of any production system is ultimately evaluated on the basis of its economic analysis. Economic analysis is used for the determination of net benefits. The economic analysis of the experiment was done to look into experimental results from farmer's point of view as they are mainly interested in benefits and cost of a certain technology and also they like to know about risks involved in the adoption of new practices. Ridge sowing under deep tillage proved to be economically viable and resulted in highest benefit cost ratio BCR. This might be due to its less cost of production and more gross income as compared with other treatments. Higher net income and BCR was recorded when the maize crop was sown on ridges [25].

\section{Conclusion}

It was concluded that ridge sowing after deep tillage gave higher grain yield, net return and BCR as compared to other tillage practices and sowing methods. Hence it was recommended that for maximum benefits maize should be planted on ridges after deep ploughing.

\section{Acknowledgements}

The authors are highly thankful to the facilities and support provided by Agro-Biology Laboratory, Department of Agronomy, University of Agriculture, Faisalabad, Pakistan.

\section{References}

[1] Hunje, R., Hanegave, A. and Nadaf, H. (2011) Effect of Seed Priming on Seed Quality of Maize (Zea mays L.). Karnataka Journal of Agricultural Sciences, 24, 237-238.

[2] Ullah, I., Ali, M. and Farooqi, A. (2010) Chemical and Nutritional Properties of Some Maize (Zea mays L.) Varieties Grown in NWFP, Pakistan. Pakistan Journal of Nutrition, 9, 1113-1117. http://dx.doi.org/10.3923/pjn.2010.1113.1117

[3] Kumar, M.A.A., Gali, S.K. and Hebsur, N.S. (2007) Effect of Different Levels of NPK on Growth and Yield Parame- 
ters of Sweet Corn. Karnataka Journal of Agricultural Sciences, 20, 41-43.

[4] Chaudhry, A.R. (1983) Maize in Pakistan. Agri. Res. Co-Ordination Board, University of Agriculture, Faisalabad, 85-86.

[5] Government of Pakistan (2011) Agricultural Statistics of Pakistan. Ministry of Food, Agriculture and Livestock, Government of Pakistan, Islamabad.

[6] Kepner, R.A., Bainer, R. and Barger, E.L. (1982) Principles of Farm Machinery. 3rd Edition, AVI Publishing, INC., Westport.

[7] Khurshid, K., Iqbal, M., Arif, M.S. and Nawaz, A. (2006) Effect of Tillage and Mulch on Soil Physical Properties and Growth of Maize. International Journal of Agriculture and Biology, 8, 593-596.

[8] Ali, M., Khalil, S.K., Ayaz, S. and Marwat, M.I. (1998) Phenological Stages, Flag Leaf Area, Plant Height, and Leaves per Plant of Corn Influenced by Phosphorus Levels and Plant Spacing. Sarhad Journal of Agriculture, 14, 515-522.

[9] Lal, R. (1990) Ridge-Tillage. Soil and Tillage Research, 18, 107-111. http://dx.doi.org/10.1016/0167-1987(90)90053-G

[10] Bewley, J.D., Black, M. and Halmer, P. (2006) The Encyclopedia of Seeds, Science, Technology and Uses. CABI Publishers, Cambridge, 509.

[11] Watson, D.J. (1947) Comparative Physiological Studies on the Growth of Field Crops. I. Variation in Net Assimilation Rate and Leaf Area between Species and Varieties and between Years. Annals of Botany, 11, 41-76.

[12] Hunt, R. (1978) Plant Growth Analysis. Edward Arnold, London, 37.

[13] Steel, R.G.D., Torrie, J.H. and Dicky, D.A. (1997) Principles and Procedures of Statistics: A Biological Approach. 3rd Edition, McGraw Hill, Inc. Book Co., New York, 352-358.

[14] CIMMYT (1988) From Agronomic Data to Farmer Recommendations: An Economic Training Manual. Completely revised Edition, Mexico. http://apps.cimmyt.org/

[15] Memon, S.Q., Baig, M.B. and Mari, G.R. (2007) Tillage Practices and Effect of Sowing Methods on Growth and Yield of Maize Crop. Agriculture Tropica et Subtrop, 40, 89-99.

[16] Bakht, J., Ahmad, S., Tariq, M., Akber, H. and Shafi, M. (2006) Response of Maize to Planting Methods and Nitrogen Fertilizer. Journal of Agricultural and Biological Sciences, 1, 8-14.

[17] Arif, M., Ihsanullah, Khan, S., Ghani, F. and Yousafzai, H.K. (2001) Response of Maize Varieties to Different Planting Methods. Sarhad Journal of Agriculture, 17, 159-163.

[18] Borghei, A.M., Taghinejad, J., Minaei, S., Karimi, M. and Varnamkhasti, M.G. (2008) Effect of Sub-Soiling on Soil Bulk Density, Penetration Resistance and Cotton Yield in Northwest of Iran. International Journal of Agriculture and Biology, 1, 120-123.

[19] Wasaya, A., Tahir, M., Manaf, A., Ahmed, M., Kaleem, S. and Ahmad, I. (2011) Improving Maize Productivity through Tillage and Nitrogen Management. African Journal of Biotechnology, 10, 19025-19034.

[20] Najafinezhad, H., Javaheri, M.A., Gheibi, M. and Rostami, M.A. (2007) Influence of Tillage Practices on the Grain Yield of Maize and Some Soil Properties in Maize-Wheat Cropping System of Iran. Journal of Agriculture and Social Sciences, 3, 87-90.

[21] Aikins, S.H.M., Afuakwa, J.J. and Owusu-Akuoko, O. (2012) Effect of Four Different Tillage Practices on Maize Performance under Rainfed Conditions. Agricultural and Biology Journal of North America, 3, 25-30. http://dx.doi.org/10.5251/abjna.2012.3.1.25.30

[22] Rasheed, M., Mahmood, T. and Shafi Nazir, M. (2003) Response of Hybrid Maize to Different Planting Methods and Nutrient Management. Pakistan Journal of Agricultural Sciences, 40, 39-42.

[23] Balasubramaniyan, P. and Palaniappan, S.P. (2001) Nutrient Management. Principles and Practices of Agronomy. Agrobios (India), Jodhpur, 185-188.

[24] Majid, A., Shafiq, M. and Iqbal, M. (1986) Deep Tillage and Sowing Techniques in Maize Production under High Rainfed Conditions. Pakistan Journal of Agricultural Research, 7, 181-185.

[25] Rehman, A., Saleem, M.F., Safdar, M.E., Hussain, S. and Akhtar, N. (2011) Grain Quality, Nutrient Use Efficiency and Bioeconomics of Maize under Different Sowing Methods and NPK Levels. Chilean Journal of Agricultural Research, 71, 586-593. http://dx.doi.org/10.4067/S0718-58392011000400014 